\title{
The prevalence and risk factors for Mallory-Weiss syndrome: a systematic review and meta-analysis
}

\author{
Abdulmajeed Albalawi ${ }^{1 *}$, Hasan Alabbadi², Tamim Almoqbell ${ }^{2}$, Omar Alsayari, \\ Abdulrahman Aljohani ${ }^{4}$, Ohoud Almana ${ }^{5}$, Amal Alenazi ${ }^{1}$, Nawal Alanazi ${ }^{1}$, Maha Al-thuwaybi ${ }^{6}$, \\ Anas Aljohani ${ }^{4}$, Mohammed Alshuhayeb ${ }^{7}$, Haya Binhashr ${ }^{5}$, Maram Almutairi ${ }^{8}$, \\ Essam Alameer", Fahad Alsuhaymi ${ }^{1}$, Dina Abusabir ${ }^{1}$
}

\author{
${ }^{1}$ Faculty of Medicine, Tabuk University, Tabuk, Saudi Arabia \\ ${ }^{2}$ Department of Emergency Medicine, Dhurma General Hospital, Dhurma, Riyadh, Saudi Arabia \\ ${ }^{3}$ Department of Surgery, King Abdulaziz Hospital, Jeddah, Saudi Arabia \\ ${ }^{4}$ College of Medicine, Taibah University, Madinah, Saudi Arabia \\ ${ }^{5}$ The program of Medicine, Ibn Sina National College, Jeddah, Saudi Arabia \\ ${ }^{6}$ College of Medicine, Taif University, Taif, Saudi Arabia \\ ${ }^{7}$ College of Medicine, Shaqra University, Shaqra, Saudi Arabia \\ ${ }^{8}$ College of Medicine, Jordan university of science and Technology, Irbid, Jordan \\ ${ }^{9}$ Faculty of Pharmacy, Jazan University, Jazan, Saudi Arabia
}

Received: 20 April 2021

Revised: 02 May 2021

Accepted: 05 May 2021

\section{*Correspondence:}

Dr. Abdulmajeed Albalawi,

E-mail: abdulmajeed.a489@gmail.com

Copyright: ( ) the author(s), publisher and licensee Medip Academy. This is an open-access article distributed under the terms of the Creative Commons Attribution Non-Commercial License, which permits unrestricted non-commercial use, distribution, and reproduction in any medium, provided the original work is properly cited.

\begin{abstract}
Mallory-Weiss syndrome (MWS), characterized by tearing and blood from mouth and stool, is a complication of gastro esophageal tract. The prevalence varies and there are a number of risk factors associated with MWS development. The present study is a systematic review and meta-analysis to determine the prevalence and various risk factors associated with Mallory-Weiss syndrome development. We systematically searched literature using specified keywords, reviewed it, and selected articles based on the inclusion and exclusion criteria. Qualitative data was presented in tables and the quantitative data was used to draw forest plots. Percentage was used to determine overall effect size for prevalence and OR and 95\% CIs was used to determine overall effect size of risk factors. Our analysis of 21 studies showed that the overall effect size for prevalence was $15.46 \%$ with $95 \%$ CI of 13.63-17.29. The pooled effect size for hiatus hernia as risk factor was found to be OR 1.96 with 95\% CI of $1.96(1.73-2.22)$. The pooled effect size for alcohol as risk factor OR 0.81 with $95 \%$ CI of $1.96(0.63-1.05)$. Finally, we found the pooled effect size for hiccups as risk factor OR 1.04 with $95 \%$ CI of 1.96 (0.78-1.39). Mallory-Weiss syndrome is not widely prevalent in various populations. There are a number of risk factors for MWS and hiatus hernia is most significant. Alcohol consumption is not strong predictor and hiccups are an emerging risk factor. There is a need for new studies with large number of subjects and controlled conditions.
\end{abstract}

Keywords: Mallory Weiss syndrome, Prevalence, Risk factors, Hiatus hernia, Alcohol 


\section{INTRODUCTION}

Mallory-Weiss syndrome characterized by a laceration in mucous membrane at gastro esophageal junction, is a disease of gastro intestinal tract. ${ }^{1}$ The condition was first described by Mallory and Weiss in $1929 .^{2}$ They observed the condition in alcoholic patients involving vomiting and persistent retching. ${ }^{3}$ According to the research, of all GIT bleeding cases up to $15 \%$ account for MWS. ${ }^{4}$ It can affect individuals of any age and race, but individuals with middle age are more affected with the condition. ${ }^{5}$ Furthermore, it has been found that men are more susceptible compared to women with 2:4.1 ratio. ${ }^{6}$

There are not always symptoms associated with MWS except minor bleeding. The most common symptoms in some cases are vomiting, retching, bloody stools and abdominal pain. ${ }^{7}$ Usually the blood appearing in vomiting is of dark red color sometimes black in the form of clots. The blood appearing in the stool is usually of black color like tar. ${ }^{8}$ The prevalence of MWS varies and range from $1-15 \%$ in various populations. For example, Hiroyuki et al found the prevalence of $9.1 \%$ and corral found it to be $3.2 \% \cdot{ }^{9,10}$

There are number of causes for MWS such as prolonged vomiting, gastritis, hiatal hernia, trauma, hiccups, coughing, and convulsions. ${ }^{11}$ A number of studies have been conducted associating various risk factors with the development of MWS. For example, Sato et al investigating the association of esophageal hiatus hernia with MWS found that the incidence of Hiatus hernia is higher in MWS patients compared to the controls. The study concluded that $\mathrm{HH}$ is the predisposing factor for MWS development. ${ }^{12}$ In contrast, Corral et al studying the relationship between $\mathrm{HH}$ and MWS found more $\mathrm{HH}$ incidence in control compared to the MWS group and concluded that $\mathrm{HH}$ is not associated with MWS.

Other studies have investigated different risk factors for MWS association. For example, a study by Dona et al found alcohol consumption and complicated course of disease associated with MWS syndrome. ${ }^{13}$ Similarly, Craft et al found out strong association of hiccups with the development of MWS. ${ }^{14}$

Although a number of studies have been conducted in past to determine the prevalence of MWS and investigate the association of different risk factors for MWS development. There is a variation and sometimes conflicting results.

Furthermore, there is no meta-analysis on the topic. So, we conducted this systematic review and meta-analysis to determine the overall effect size for the prevalence of MWS and to see how strongly different risk factors such as Hiatus hernia, alcohol consumption, GERD etc. are associated with the development of th MWS.

\section{METHODS}

\section{Study selection}

The study was conducted according to the preferred reporting for systematic reviews and meta-analysis (PRISMA) guidelines. The studies included in the SR were case-control, cross sectional, prospective and retrospective. Any population, age group, gender group, and race were included. The studies were excluded if the studies were case reports, not in English language.

\section{Duration}

This systematic review and meta-analysis were conducted from 10 March, 2021 to 12 April, 2021.

\section{Literature search strategy}

We did the literature search in online databases such as PubMed Medline, Embase, Cochrane library, Google scholar and Science direct. The key words used for the search were "Mallory Weiss syndrome" "Gastroesophageal Laceration-Hemorrhage" "MalloryWeiss" Laceration Mallory-Weiss Tear" "Hiatus hernia" "Alcohol" "GERD" "Prevalence" Risk factor."

The initial article identification was performed based on title and abstract reading by two separate investigators. Later, full articles were reviewed for potential exclusion. The articles which did not fall in inclusion criteria were excluded and remaining full text articles were stored for data extraction.

\section{Data extraction}

Two separate investigators extracted the data from studies. The data extracted were study related such as author's information, date of publication, country of origin. The patient's related data extracted were condition, age, gender, race and other information available. Finally, the data required for MA such as prevalence and OR was extracted. 2 separate investigators performed all steps and if any conflict was found, it was resolved with discussion.

\section{Quality assessment of studies}

The studies included in this SR and MA was assessed for their quality using new castle Ottawa scare (NOS). According to the scale the score $>7$ was considered as high-quality studies, the score 5-7 was medium quality studies and the score $<5$ was labeled as low-quality studies.

\section{Statistical analysis}

The standard forest plots were used to see the overall effect sizes of various measures. For prevalence, we used mean \%ages and their $95 \%$ CIs will use to draw forest 
plots. For risk factors association, we used OR and their 95\% CIs. To determine heterogeneity, $\mathrm{I}^{2}$ test and the Cochrane's Q statistic was used. $\mathrm{I}^{2}$ value of $<50 \%$ will be considered low heterogeneity, $\mathrm{I}^{2}$ value of $50-75 \%$ considered as moderate and $\mathrm{I}^{2}$ value $>50 \%$ considered as high heterogeneity. Finally, funnel plots were used to determine publication bias.

\section{RESULTS}

The literature search initially yielded 540 articles. Based on the Titles and abstract screening, 440 articles were excluded. Full texts of the remaining 100 articles were reviewed which left with 30 articles. After duplication removal 21 articles (15-35) were left which were included in the final analysis. The literature search procedure is summarized in Figure 1.

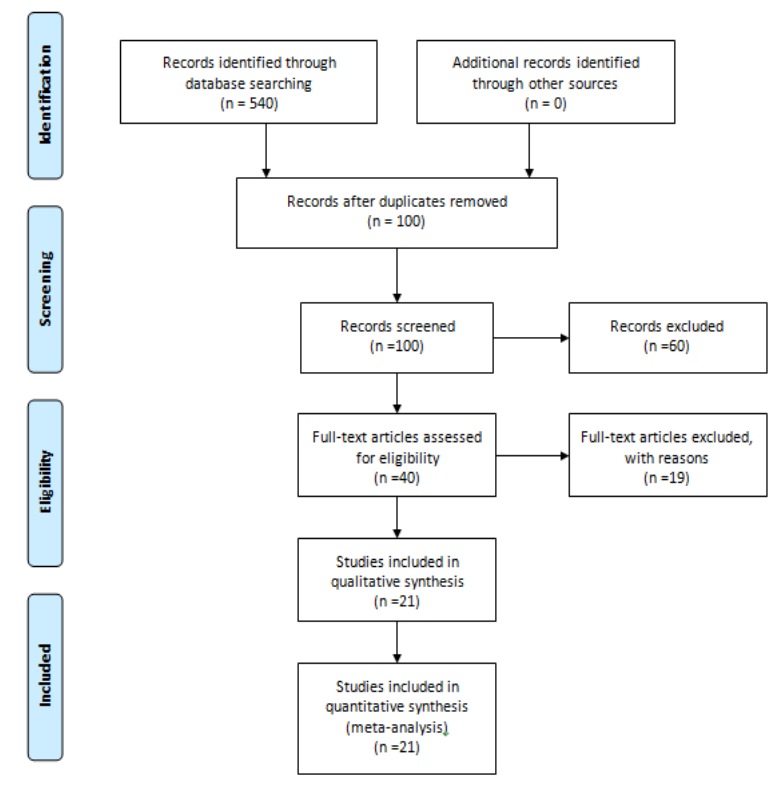

Figure 1: PRISMA diagram elaborating literature search procedure.

\section{Study and patient characteristics}

21 studies were included in this SR and MA discussing prevalence and risk factors associated with MWS. 15 of the studies had provided prevalence of MWS. The risk factors studied were Hiatus Hernia, Alcohol, and Hiccups etc. The majority of studies were about Hiatus Hernia as risk factor for MWS (12 studies). 5 studies discussed Alcohol as risk factor for MWS and the remaining 4 studies were about Hiccups as risk factor for MWS. Regarding the study designs of the included studies, mostly (11) were case control study, 4 retrospective, 4 prospective, and 2 cross sectionals.

Geographic distribution of studies was as follows: $37 \%$ were from Asia, 33\% from the United States, 14\% from
Europe, $10 \%$ from the Middle East, and 6\% from South America. Further study and patient characteristics are summarized in. Total number of subjects in all 21 studies was 621.300 were patients and 321 were control subjects.

There were 12 studies related to hiatus hernia as risk factor. The total numbers of patients were 232, among which $28 \%$ were women, and $72 \%$ were men. Mostly the patients were White Europeans and the mean age calculated was 42.32 years. In Alcohol related studies, there were 131 patients. Mostly white Europeans with the mean age of 39.85 . Finally Hiccups related studies have 92 subjects all chines and European origin and the mean age was 32.32 .

With respect to the study quality, 13 scored $>7$ at NOS scale, thus considered high quality, 3 were medium quality (scored 5-7) and the remaining 5 studies were of low quality (NOS score<5).

\section{Meta-analysis of prevalence}

There were 20 studies which provided the data for prevalence. Based on our analysis the pooled prevalence was $15.46 \%$ with $95 \%$ CI of 13.63-17.29. The lowest prevalence was found to be 7 and the highest was 45 . We found the high heterogeneity between studies with $\mathrm{I}^{2}>75 \%$. Meta-analysis is depicted in Figure 2.

\section{Meta-analysis of hiatus hernia as risk factor for MWS}

There were 12 studies about the hiatus hernia as risk factor for MWS. The pooled effect size was found to be OR 1.96 with $95 \%$ CI of 1.96 (1.73-2.22). $30 \%$ of the studies were significant for non-association and $70 \%$ were significant for association. The overall effect size showed that $\mathrm{HH}$ is a significantly associated with the development of MWS (Figure 3).

\section{Meta-analysis of alcohol as risk factor for MWS}

There were 5 studies about the alcohol as risk factor for MWS. The pooled effect size was found to be OR 0.81 with $95 \%$ CI of $1.96(0.63-1.05) .60$ of the studies were significant for non-association and $70 \%$ were significant for association. The overall effect size showed that alcohol is not a significantly associated with the development of MWS (Figure 4).

\section{Meta-analysis of hiccups as risk factor for MWS}

There were 5 studies about the hiccups as risk factor for MWS. The pooled effect size was found to be OR 1.04 with $95 \%$ CI of $1.96(0.78-1.39) .50 \%$ of the studies were significant for non-association and $50 \%$ were significant for association. The overall effect size showed that Hiccups is significantly associated with the development of MWS (Figure 5). 


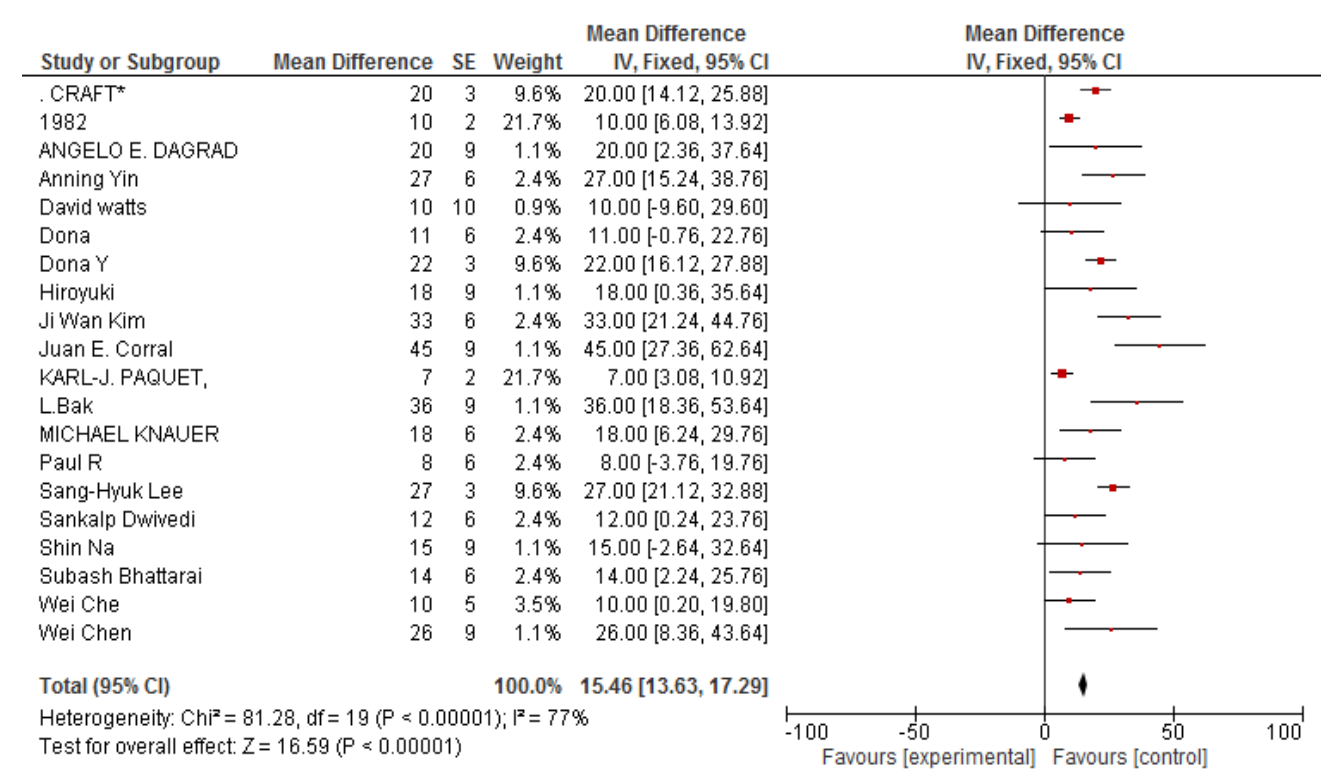

Figure 2: Meta-analysis of the prevalence of MWS.

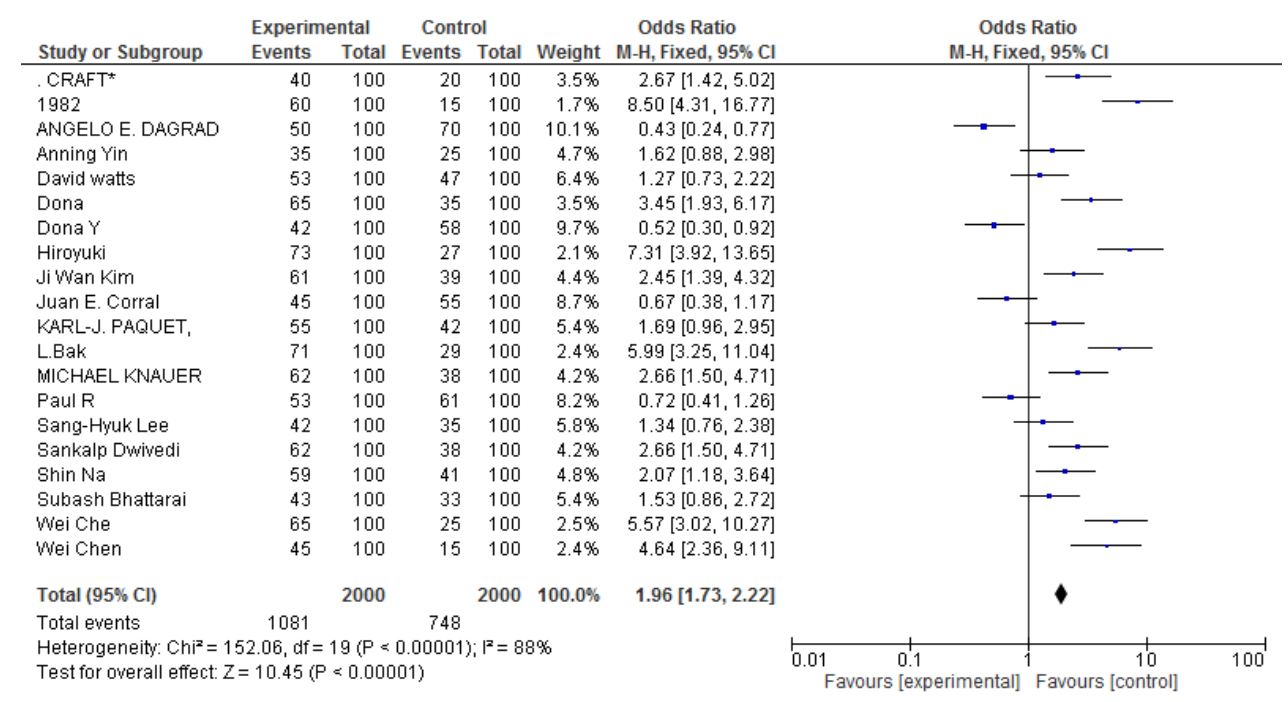

Figure 3: Meta-analysis of $\mathrm{HH}$ as risk factor for MWS.

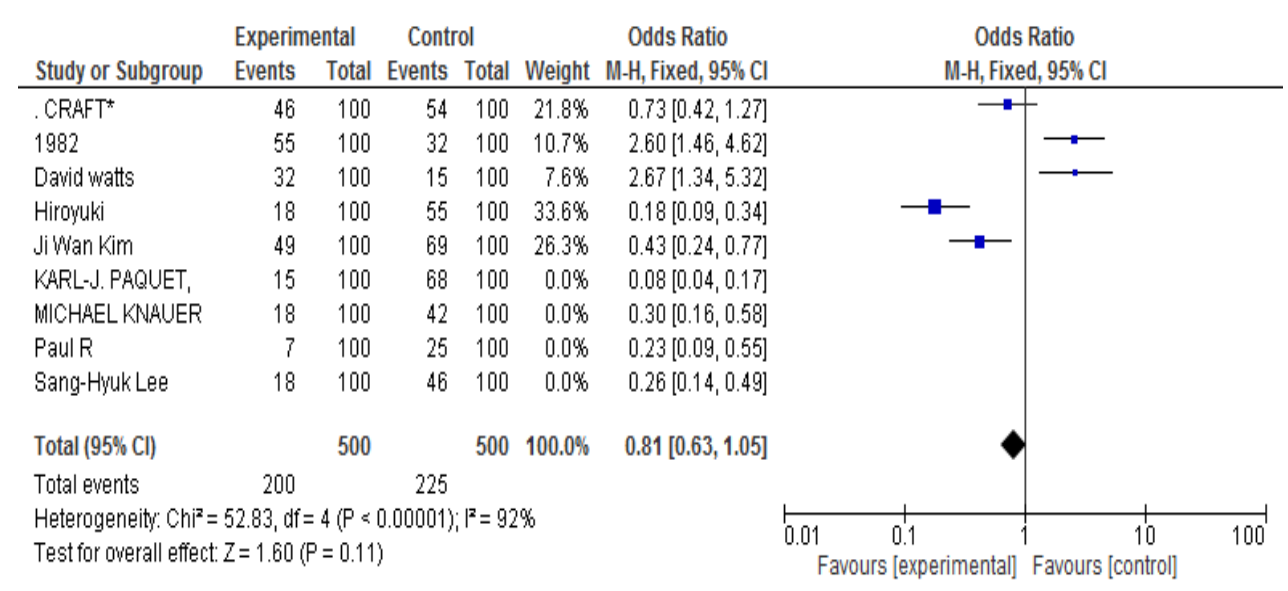

Figure 4: Meta-analysis of alcohol as risk factor for MWS. 
Table 1: The above table summarizes the study and patient related characteristics.

\begin{tabular}{|c|c|c|c|c|c|c|c|}
\hline $\begin{array}{l}\text { Study } \\
\text { ID }\end{array}$ & $\begin{array}{l}\text { First } \\
\text { Authors }\end{array}$ & $\begin{array}{l}\text { Publication } \\
\text { years }\end{array}$ & $\begin{array}{l}\text { sample } \\
\text { sizes }\end{array}$ & Study designs & Country & Risk factors & Patient characteristics \\
\hline \multirow[t]{2}{*}{1} & \multirow[t]{2}{*}{ Hiroyuki } & \multirow[t]{2}{*}{1989} & \multirow[t]{2}{*}{$\begin{array}{l}103 \\
80 \\
\text { controls } \\
23 \text { patients }\end{array}$} & \multirow[t]{2}{*}{ Retrospective } & \multirow[t]{2}{*}{ Japan } & \multirow[t]{2}{*}{ Hiatus hernia } & $\begin{array}{l}\text { A. Mallory-Weiss syndrome } \\
\text { 1. Number of cases: } 23(21 \text { males and } 2 \text { females }), 2 . \\
\text { Average age: } 45.1+12.8 \sim \text { ', } 3 \text {. Number of habitual } \\
\text { drinkers: } 15(65.2 \%), 4 \text {. Causes of vomiting: } \\
\text { Overdrinking } 13(56.6 \%) \text {, Gastroduodenal disease } 4 \\
(17.4 \%) \text {, Endoscopic examination } 3(13.0 \%) \text {, } \\
\text { Hemodialysis } 1(4.3 \%) \\
\text { Unknown } 2(8.7 \%)\end{array}$ \\
\hline & & & & & & & $\begin{array}{l}\text { B. Control group } \\
\text { 1. Number of cases: } 80 \text { ( } 56 \text { males and } 24 \text { females }), 2 \text {. } \\
\text { Average age: } 44.7-+10.1 \#, 3 \text {. Number of habitual } \\
\text { drinkers: } 28(35.0 \%)\end{array}$ \\
\hline 2 & $\begin{array}{l}\text { Juan E. } \\
\text { Corral }\end{array}$ & 2016 & $\begin{array}{l}11712 \\
2342 \\
\text { patients } \\
9368 \\
\text { controls }\end{array}$ & $\begin{array}{l}\text { Matched case } \\
\text { control }\end{array}$ & US & Hiatus hernia & $\begin{array}{l}\text { Average age was } 56.7 \pm 18.6 \text { years, and } 1696 \\
(72.43 \%) \text { were male (same in both groups). The } \\
\text { majority of patients were non-Hispanic whites }(1545 \\
(65.97 \%) \text { in MWS and } 7467(79.71 \%) \text { in controls }\end{array}$ \\
\hline 3 & Dona Y. & 2001 & 73 & Retrospective & US & $\begin{array}{l}\text { Alcohol use } 32 \text { (44), Alcohol } \\
\text { binge } 13 \text { (18), Anticoagulation } \\
7(10), \text { Other coagulopathy } 6 \\
(8) \\
\text { NSAID use } 17(23) \text {, Non- } \\
\text { bloody initial emesis } 11(15) \text {, } \\
\text { Hiatal hernia } 12(16) \text {, None of } \\
\text { the above } 17(23)\end{array}$ & \\
\hline 4 & $\begin{array}{l}\text { Angelo E. } \\
\text { Dagrad }\end{array}$ & 1966 & 30 & Retrospective & US & Alcohol & $\begin{array}{l}\text { All } 30 \text { patients in this series were men ranging in age } \\
\text { from } 31 \text { to } 64 \text { years; the majority }(71 \%) \text { were in the } \\
30 \text { - to } 49 \text {-year age group. }\end{array}$ \\
\hline 5 & Shin $\mathrm{Na}$ & 2017 & 1001 & Retrospective & $\begin{array}{l}\text { South } \\
\text { Korea }\end{array}$ & $\begin{array}{l}\text { Age, } \\
\text { Sex } \\
\text { Diabetes mellitus } \\
\text { Hypertension } \\
\text { Liver disease } \\
\text { Antiplatelet } \\
\text { Anticoagulant } \\
\text { History of distal gastrectomy } \\
\text { Reflux esophagitis } \\
\text { Sedation }\end{array}$ & $\begin{array}{l}\text { Median age, years (IQR, years) } 53 \text { (43-64) } \\
\text { Sex-(M/F) 330/216 } \\
\text { Diabetes mellitus-43 (7.9), Hypertension-130 (23.8), } \\
\text { Liver disease-38 (6.9) }\end{array}$ \\
\hline
\end{tabular}




\begin{tabular}{|c|c|c|c|c|c|c|c|}
\hline $\begin{array}{l}\text { Study } \\
\text { ID }\end{array}$ & $\begin{array}{l}\text { First } \\
\text { Authors }\end{array}$ & $\begin{array}{l}\text { Publication } \\
\text { year }\end{array}$ & $\begin{array}{l}\text { sample } \\
\text { size }\end{array}$ & Study design & Country & Risk factor & Patient characteristics \\
\hline 6 & Wei Chen & 2019 & 20 & Retrospective & China & Gender, procedure time & 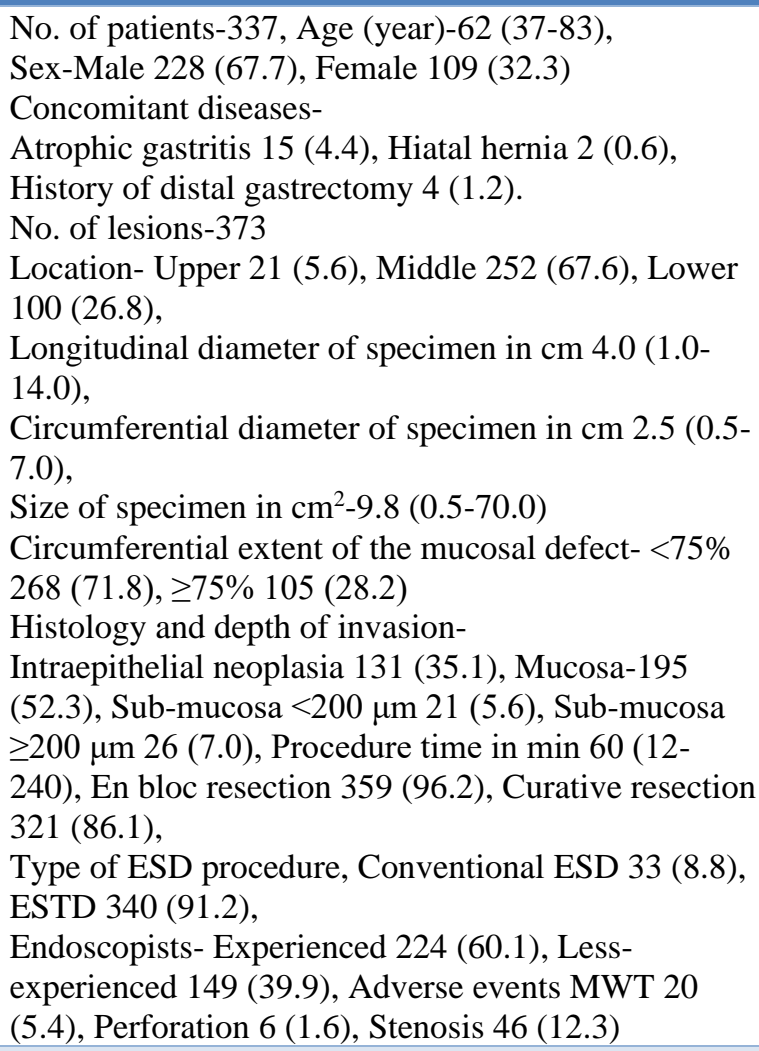 \\
\hline 7 & $\begin{array}{l}\text { Subash } \\
\text { Bhattarai }\end{array}$ & 2017 & 600 & $\begin{array}{l}\text { Cross } \\
\text { sectional }\end{array}$ & Nepal & Hiatus hernia & $\begin{array}{l}\text { Patients with Mallory Weiss tear were aged between } \\
19 \text { and } 75 \text { years of age (mean } 45.8 \pm 16.16 \text { years). The } \\
\text { mean ages of male and female patients were } 49.6 \text { and } \\
39.8 \text { years respectively (Male:Female }=1.6: 1 \text { ). }\end{array}$ \\
\hline 8 & L. Bak & 1999 & 2720 & $\begin{array}{l}\text { Cross } \\
\text { sectional }\end{array}$ & Poland & & 6-17 years \\
\hline 9 & Dona Y & 2001 & 73 & Retrospective & US & $\begin{array}{l}\text { Alcohol use } 32 \text { (44), Alcohol } \\
\text { binge } 13 \text { (18), } \\
\text { Anticoagulation } 7(10), \\
\text { Other coagulopathy } 6(8), \\
\text { NSAID use } 17 \text { (23) } \\
\text { Nonbloody initial emesis } 11 \\
\text { (15), Hiatal hernia } 12(16) \text {, } \\
\text { None of the above } 17 \text { (23) }\end{array}$ & \\
\hline
\end{tabular}




\begin{tabular}{|c|c|c|c|c|c|c|c|}
\hline $\begin{array}{l}\text { Study } \\
\text { ID }\end{array}$ & $\begin{array}{l}\text { First } \\
\text { Authors }\end{array}$ & $\begin{array}{l}\text { Publication } \\
\text { year }\end{array}$ & $\begin{array}{l}\text { sample } \\
\text { size }\end{array}$ & Study design & Country & Risk factor & Patient characteristics \\
\hline 10 & $\begin{array}{l}\text { Choichi } \\
\text { Sugawa }\end{array}$ & 1982 & 2175 & Retrospective & US & & $\begin{array}{l}\text { Consisted of } 46 \text { women ( } 20.5 \text { percent) with a mean } \\
\text { age of } 41 \text { years (range } 22 \text { to } 78 \text { years) and } 178 \text { men } \\
\text { ( } 79.5 \text { percent) with a mean age of } 38 \text { years (range } 13 \\
\text { to } 86 \text { years). One hundred ninety-four ( } 86 \text { percent) of } \\
\text { the patients had a history of violent vomiting, } \\
\text { retching, coughing, or straining, and } 68 \text { ( } 31 \text { percent) } \\
\text { of the patients had a history of excessive drinking or } \\
\text { physical findings consistent with chronic alcohol } \\
\text { abuse. Many of them presented with acute alcoholic } \\
\text { intoxication. Thirteen ( } 6 \text { percent) had concomitant } \\
\text { pancreatitis, } 184 \text { patients ( } 82 \text { percent) had a single } \\
\text { tear, } 23 \text { ( } 10.2 \text { percent) had two lacerations, and } 16 \text { ( } 7 \\
\text { percent) had three lacerations. One patient had four } \\
\text { tears identified. Eighty-three percent of Mallory- } \\
\text { Weiss tears were located just below the gastr- } \\
\text { oesophageal junction on the lesser curve of the } \\
\text { stomach as shown in the Figure } 1,9.9 \text { percent were } \\
\text { located on the greater curve of the stomach, and } 4.4 \\
\text { and } 2.7 \text { percent were located on the posterior and } \\
\text { anterior surfaces, respectively. Although none of the } \\
\text { tears were confined to the esophagus, } 8.7 \% \text { tof them } \\
\text { extended into the esophagus. The average length of } \\
\text { the Mallory-Weiss tear was } 2.1 \text { cm. }\end{array}$ \\
\hline 11 & $\begin{array}{l}\text { Michael } \\
\text { Knauer }\end{array}$ & 1976 & 528 & $\begin{array}{l}\text { Cross } \\
\text { sectional }\end{array}$ & US & Hiatal hernia & $\begin{array}{l}\text { Forty-six of the } 58 \text { ( } 77.4 \text { percent) patients with } \\
\text { Mallory Weiss lacerations were male, approximating } \\
\text { the } 71 \% \text { male predominance of the } 528 \text { upper } \\
\text { gastrointestinal bleeders endoscoped, the average age } \\
\text { was } 45.2 \text { - and } 49.4 \text {-years male and female, } \\
\text { respectively. Twenty-two of the } 58 \text { ( } 38 \text { percent) } \\
\text { Mallory-Weiss patients were seen in the } 3 \text {-month } \\
\text { period of November through January, but this } \\
\text { apparently high incidence is not statistically } \\
\text { significant. The clinical features of these patients } \\
\text { include excessive alcohol intake alone in } 23 \text { of } 58 \text { ( } 40 \\
\text { percent), acetylsalicylic acid alone in } 11 \text { ( } 20 \text { percent), } \\
\text { and both in } 16 \text { ( } 27.5 \text { percent). Symptoms of emesis or } \\
\text { retching preceded actual upper gastrointestinal } \\
\text { bleeding in } 43 \text { of } 58 \text { ( } 74 \text { percent) patients. }\end{array}$ \\
\hline 12 & $\begin{array}{l}\text { Karl-j. } \\
\text { Paquet, }\end{array}$ & 1989 & 139 & $\begin{array}{l}\text { Cross } \\
\text { sectional }\end{array}$ & Germany & & \\
\hline
\end{tabular}

International Journal of Community Medicine and Public Health | June 2021 | Vol 8 | Issue 6 Page 3102 


\begin{tabular}{|c|c|c|c|c|c|c|c|}
\hline $\begin{array}{l}\text { Study } \\
\text { ID }\end{array}$ & $\begin{array}{l}\text { First } \\
\text { Authors }\end{array}$ & $\begin{array}{l}\text { Publication } \\
\text { year }\end{array}$ & $\begin{array}{l}\text { sample } \\
\text { size }\end{array}$ & Study design & Country & Risk factor & Patient characteristics \\
\hline 13 & Ji Wan Kim & 2015 & 329 & Retrospective & $\begin{array}{l}\text { South } \\
\text { Korea }\end{array}$ & & \\
\hline 14 & Wei Chen & 2019 & 20 & Retrospective & China & Gender, procedure time & $\begin{array}{l}\text { No. of patients-337, } \\
\text { Age (years) } 62(37-83) \\
\text { Sex- Male } 228(67.7), \text { Female } 109(32.3) \\
\text { Concomitant diseases- } \\
\text { Atrophic gastritis } 15(4.4), \text { Hiatal hernia } 2(0.6), \\
\text { History of distal gastrectomy } 4(1.2) . \\
\text { No. of lesions-373 } \\
\text { Location- Upper } 21 \text { (5.6), Middle } 252(67.6), \text { Lower } \\
100(26.8), \text { Longitudinal diameter of specimen in cm } \\
4.0(1.0-14.0)\end{array}$ \\
\hline 15 & S. Dwivedi & 2017 & 213 & Retrospective & India & Hiccups & \\
\hline 16 & Craft* & 1967 & 321 & Retrospective & US & Hiccups & $\begin{array}{l}\text { Median age, years (IQR, years)-53 (43-64) } \\
\text { Sex-(M/F) 330/216, Diabetes mellitus-43 (7.9), } \\
\text { Hypertension } 130 \text { (23.8), Liver disease } 38 \text { (6.9) }\end{array}$ \\
\hline 17 & Anning Yin & 2012 & 519 & retrospective & China & & $\begin{array}{l}\text { The median age was } 43.3 \text { years, ranging from } 19 \text { to } \\
78 \text { years. Most patients presented with melena and/or } \\
\text { hematemesis }\end{array}$ \\
\hline 18 & Paul R & 1981 & 69 & Retrospective & US & Alcohol & $\begin{array}{l}\text { There were } 47 \text { men and } 22 \text { women. Fifty-three } \\
\text { patients were black, } 15 \text { were Caucasian and } 1 \text { was } \\
\text { oriental. Their ages ranged from } 20 \text { to } 79 \text { years (mean } \\
44.9 \text { ). This syndrome occurred most commonly in the } \\
\text { fourth, } 5^{\text {th }} \text { and } 6^{\text {th }} \text { decades of life. }\end{array}$ \\
\hline 19 & David Watts & 1974 & 36 & Retrospective & US & & $\begin{array}{l}\text { Mean age: } 46.39 \\
\text { Male: } 69 \text { Female: } 31\end{array}$ \\
\hline 20 & $\begin{array}{l}\text { Sang-Hyuk } \\
\text { Lee }\end{array}$ & 2006 & 12521 & Retrospective & China & & $\begin{array}{l}\text { Mean age- } 48.8 \text { years and m:f-18.5:1. The frequent } \\
\text { precipitating factor was vomiting developed after } \\
\text { drinking (65\%). In these patients ( } 110 \text { cases), } 42 \\
\text { cases }(38 \%) \text { occurred in winter, } 21 \text { cases }(19 \%) \text { in } \\
\text { spring, } 31 \text { cases ( } 28 \%) \text { in summer and } 16 \text { cases } \\
\text { (15\%) in fall. Endoscopic findings revealed active } \\
\text { bleeding in } 33 \text { cases }(21 \%) \text {, blood clot without active } \\
\text { bleeding in } 87 \text { cases ( } 56 \%) \text {, and scar change in } 36 \\
(23 \%) . \text { In } 113 \text { cases ( } 72 \%) \text {, coexisting diseases such } \\
\text { as gastritis, gastric ulcer and esophageal varix were } \\
\text { detected. MW tears were located on gastric area in } 25 \\
\text { cases }(16 \%) \text {, on lower esophagus in } 16 \text { cases } \\
(10.4 \%) \text {, on gastro-esophageal junction in } 114(73 \%) \text {, } \\
\text { on gastro-esophagus in } 1(0.6 \%) \text {. }\end{array}$ \\
\hline
\end{tabular}




\begin{tabular}{|c|c|c|c|c|c|c|c|c|c|c|}
\hline \multirow[b]{2}{*}{ Study or Subgroup } & \multicolumn{2}{|c|}{ Experimental } & \multicolumn{2}{|c|}{ Control } & \multicolumn{2}{|r|}{ Odds Ratio } & \multirow{2}{*}{\multicolumn{3}{|c|}{$\begin{array}{c}\text { Odds Ratio } \\
\text { M-H, Fixed, } 95 \% \mathrm{Cl}\end{array}$}} & \\
\hline & Events & Total & Events & Total & Weight & M-H, Fixed, $95 \% \mathrm{Cl}$ & & & & \\
\hline CRAFT* & 46 & 100 & 54 & 100 & $31.9 \%$ & $0.73[0.42,1.27]$ & & $\rightarrow$ & & \\
\hline 1982 & 55 & 100 & 32 & 100 & $15.7 \%$ & $2.60[1.46,4.62]$ & & & $\longrightarrow$ & \\
\hline David watts & 32 & 100 & 15 & 100 & $11.1 \%$ & $2.67[1.34,5.32]$ & & & $\longrightarrow$ & \\
\hline Hiroyuki & 18 & 100 & 55 & 100 & $0.0 \%$ & $0.18[0.09,0.34]$ & & & & \\
\hline Ji Wan Kim & 49 & 100 & 69 & 100 & $0.0 \%$ & $0.43[0.24,0.77]$ & & & & \\
\hline KARL-J. PAQUET, & 15 & 100 & 68 & 100 & $0.0 \%$ & $0.08[0.04,0.17]$ & & & & \\
\hline MICHAEL KNAUER & 18 & 100 & 42 & 100 & $0.0 \%$ & $0.30[0.16,0.58]$ & & & & \\
\hline PaulR & 7 & 100 & 25 & 100 & $0.0 \%$ & $0.23[0.09,0.55]$ & & & & \\
\hline Sang-Hyuk Lee & 18 & 100 & 46 & 100 & $41.2 \%$ & $0.26[0.14,0.49]$ & & $\rightarrow-$ & & \\
\hline Total (95\% Cl) & & 400 & & 400 & $100.0 \%$ & $1.04[0.78,1.39]$ & & & & \\
\hline Total events & 151 & & 147 & & & & & & & \\
\hline $\begin{array}{l}\text { Heterogeneity: } \mathrm{Chi}^{2}= \\
\text { Test for overall effect }\end{array}$ & $\begin{array}{l}36.45, \mathrm{df} \\
Z=0.29\end{array}$ & $\begin{array}{l}3(P<0 \\
=0.77)\end{array}$ & $0.00001)$ & $i^{2}=92$ & & & 0.01 & 0.11 & Favours lo & $\begin{array}{c}10 \\
10\end{array}$ \\
\hline
\end{tabular}

Figure 5: Hiccups as a risk factor for MWS.

\section{DISCUSSION}

Mallory-Weiss syndrome is a gastro esophageal disease with varied prevalence reporting and the number of risk factors associated. This is a systematic review and metaanalysis of the prevalence of MWS and the associated risk factors. The first SR and MA on the topic have combined 21 studies and more than 600 subjects.

Our study has found the overall prevalence of $15.46 \%$. The studies in the past have reported varied prevalence in a range of races from $7 \%$ to $45 \% .{ }^{36,37}$ The analysis further revealed that the subjects were of middle age and men were more compared to women. This is in line with the previous studies where it has been found that mostly men of middle age are affected with MWS. ${ }^{38,39}$ Furthermore, it was also discovered that subjects of European descent were mostly affected..$^{40}$

Studies in that past have shown association with the number of factors for the development of MWS. We considered factors as hiatus hernia, Alcohol, and hiccups as association for MWS. Our analysis has shown that hiatus hernia is significantly associated with development of MWS. The studies in the past have conflicting conclusions. Some have considered hiatus hernia as a strong predicting factor for MWS while other have not considered it as a strong risk factor for MWS development. ${ }^{41,42}$ There can be the number of reasons for this conflicting result and one of the reasons is the poor randomization and selection of subjects. ${ }^{43}$ Another important risk factor discussed in this analysis was Alcohol. Studies in the past have shown that individuals diagnosed with MWS were mostly binge alcoholics so Alcohol was considered as important associating factor. ${ }^{44}$ Our analysis finds very week association of alcohol with MWS development. An emerging risk factor being discussed in the literature was hiccups. Scholars found that people visiting hospitals with complication and symptoms of MWS were having continuous hiccups. ${ }^{45}$ Our analysis also revealed that hiccups are associated with the development of MWS.
Like most of other studies our studies also have some limitations. First, there is a significant number of crosssectional studies involved for conducting meta-analysis. The evidence presented by cross-sectional studies is of poorer quality compared to that presented by case-control studies. Besides, the studies were heterogeneous. Although the studies considered here had a number of confounding variables such as gender, age, and ethnicity, we did not perform a subgroup analysis based on these variables, which can affect the results. Finally, the studies had a publication bias as well.

\section{CONCLUSION}

MWS is a complication of gastro esophageal tract with a number of associated factors. The prevalence of MWS is not extensive in individuals with GIT tract complications. Hiatus hernia is strongly associated with the development of MWS. Alcohol is not a strong predictor for MWS development. An emerging risk factor showing strong association was Hiccups. There is a need of new studies with controlled conditions to properly predict risk factors.

Funding: No funding sources Conflict of interest: None declared Ethical approval: Not required

\section{REFERENCES}

1. Dagradi AE, Broderick JT, Juler G, The MalloryWeiss syndrome and lesion. A study of 30 cases. Am J Dig Dis. 1966;11:710-72.

2. Weaver DH, Maxwell JG, Castleton KB. MalloryWeiss syndrome. Am J Surg. 1969;18:887-92.

3. Miller AC Jr, Hirschowitz BI. Twenty-three patients with Mallory-Weiss syndrome. South Med J. 1970;63:441-44.

4. Watts HD. Admirand WH: MaUory-Weiss syndrome. A reappraisal. JAMA. 1974;230:728-34.

5. Knauer CM. Mallory-Weiss syndrome. Characterization of 75 Mallory-Weiss lacerations in 
528 patients with upper gastrointestinal hemorrhage. Gastroenterology. 1976;71:5.

6. Dagradi AE, Broderick JT, Juler G. The MalloryWeiss syndrome and lesion. A study of 30 cases. Am J Dig Dis. 1966;11:710-21.

7. Sato H, Takase S, Takada A. The association of esophageal hiatus hernia with Mallory-Weiss syndrome. Gastroenterol Jpn 1989;24:233-8.

8. Chen YL. Mechanical gastritis as cause of upper gastrointestinal hemorrhage. Scand J Gastroenterol 1993;28:512-4.

9. American Society of Gastrointestinal Endoscopy (ASGE). CORI Overview 2016. Available at: http:// www.asge.org/about/about.aspx? $\mathrm{id}^{1 / 41114}$. Accessed on 2016 Nov 20.

10. Ramsey PJ, Shaib YH, Graham DY. Appropriate use or overutilization of the CORI database? Am J Gastroenterol. 2009;104:785-6.

11. Knauer CM. Mallory-Weiss syndrome, characterization of 75 Mallory-Weiss lacerations in 528 patients with upper gastrointestinal hemorrhage. Gastroenterology. 1976;71:5-8.

12. Hixson SC, Burns RP, Britt LG. Mallory-Weiss syndrome: Retrospective review of eight years' experience. South Med J. 1979;72:1249-51.

13. Hastings PR, Peters KW, Cohn I. Mallory-Weiss syndrome. Am J Surg. 1981;142:560-2.

14. Dagradi AE, Broderick JT, Juler G, et al. The Mallory-Weiss syndrome and lesion-A study of 30 cases. Am J Dig Dis. 1966;11:710-21.

15. Penston JG, Boyd EJS, Wormsley KG. MalloryWeiss tears occurring during endoscopy: A report of seven cases. Endoscopy. 1992;24:262-5.

16. Atkinson M, Botrill MB, Edwards AT. Mucosal tears at the oesophagogastric junction (the Mallory-Weiss syndrome). Gut. 1961;2:1-11.

17. Raymond PL. Mallory-Weiss tear associated with polyethylene glycol electrolyte lavage solution. Gastrointest Endosc. 1991;37:410-1.

18. Baker RW, Spiro AH, Trnka YM. Mallory-Weiss tear complicating upper endoscopy: Case reports and review of the literature. Gastroenterol. 1982;82:1402.

19. Santoro MJ, Chen YK, Collen MJ. Polyethylene glycol electrolyte lavage solution-induced MalloryWeiss tears. Am J Gastroenterol. 1993;88:1292-3.

20. Bharucha AE, Gostout CJ, Balm RK. Clinical and endoscopic risk factors in the Mallory-Weiss Syndrome. Am J Gastroenterol. 1997;92:805-8.

21. Bataller R, Llach J, Salmeron JM. Endoscopic sclerotherapy in upper gastrointestinal bleeding due to the Mallory-Weiss syndrome. Am J Gastroenterol. 1994;89:2147-50.

22. Mallory GK, Weiss S. Hemorrhages from laceration of cardia orifice of the stomach due to vomiting. Am J Med Sci. 1929;178(4):506-10.

23. Di Fiore F, Lecleire S, Merle V. Changes in characteristics and outcome of acute upper gastrointestinal haemorrhage: a comparison of epidemiology and practices between 1996 and 2000 in a multicentre French study. Eur J Gastroenterol Hepatol. 2005; 17(6):641-7.

24. Lecleire S, Di Fiore F, Merle V. Acute upper gastrointestinal bleeding in patients with liver cirrhosis and in noncirrhotic patients: epidemiology and predictive factors of mortality in a prospective multicenter population-based study. J Clin Gastroenterol. 2005;39(4):321-7.

25. Kortas DY, Haas LS, Simpson WG, Nickl NJ $3^{\text {rd }}$, Gates LK Jr. Mallory-Weiss tear: predisposing factors and predictors of a complicated course. Am J Gastroenterol. 2001;96(10):2863-5.

26. Chung IK, Kim EJ, Hwang KY. Evaluation of endoscopic hemostasis in upper gastrointestinal bleeding related to Mallory-Weiss syndrome. Endoscopy. 2002;34(6):474-9.

27. Bharucha AE, Gostout CJ, Balm RK. Clinical and endoscopic risk factors in the Mallory-Weiss syndrome. Am J Gastroenterol. 1997;92(5):805-8.

28. Yuan Y, Wang C, Hunt RH. Endoscopic clipping for acute nonvariceal upper-GI bleeding: a meta-analysis and critical appraisal of randomized controlled trials. Gastrointestinal Endoscopy. 2008;68(2):339-51

29. Watts HD. Mallory-Weiss syndrome occurring as a complication of endoscopy. Gastrointestinal Endoscopy, 1976;22(3):171-2.

30. Montalvo RD, Lee M. Retrospective analysis of iatrogenic Mallory-Weiss tears occurring during upper gastrointestinal endoscopy. HepatoGastroenterolog. 1996;43(7):174-7.

31. Penston JG, Boyd EJ, Wormsley KG. Mallory-Weiss tears occurring during endoscopy: a report of seven cases. Endoscopy. 1992;24(4):262-5.

32. Shimoda R, Iwakiri R, Sakata H. Endoscopic hemostasis with metallic hemoclips for iatrogenic Mallory-Weiss tear caused by endoscopic examination. Digestive Endoscopy. 2009;21(1):20-23.

33. Park $\mathrm{CH}$, Min SH, Sohn YH. A prospective, randomized trial of endoscopic band ligation vs. epinephrine injection for actively bleeding MalloryWeiss syndrome. Gastrointestinal Endoscopy. 2004;60(1):22-7.

34. Higuchi N, Akahoshi K, Sumida Y. Endoscopic band ligation therapy for upper gastrointestinal bleeding related to Mallory-Weiss syndrome. Surg Endoscopy. 2006;20(9):1431-4.

35. Huang SP, Wang HP, Lee YC. Endoscopic hemoclip placement and epinephrine injection for MalloryWeiss syndrome with active bleeding. Gastrointestinal Endoscopy. 2002;55(7):842-6.

36. Will U, Seidel T, Bosseckert H. Endoscopic hemoclip treatment for bleeding artificially induced Mallory-Weiss tears. Endoscopy. 2002;34(9):74.

37. Katsumi YN. Endoscopic hemoclipping for upper GI bleeding due to MalloryWeiss syndrome. Gastrointestinal Endoscopy. 2001;53(4):427-30.

38. Armstrong D, Bennett JR, Blum AL. The endoscopic assessment of esophagitis: a progress report on 
observer agreement. Gastroenterology. 1996;111(1):85-92.

39. Myung SJ, Kim HR, Moon YS. Severe MalloryWeiss tear after endoscopy treated by endoscopic band ligation. Gastrointestinal Endoscopy. 2000;52(1):99-101.

40. Matsui S, Kamisako $\mathrm{T}$, Kudo $\mathrm{M}$, Inoue $\mathrm{R}$. Endoscopic band ligation for control of nonvariceal upper GI hemorrhage: comparison with bipolar electrocoagulation. Gastrointestinal Endoscopy. 2002;55(2):214-8.

41. Papp JP. Electrocoagulation of actively bleeding Mallory-Weiss tears. Gastrointestinal Endoscopy. 1980;26(4):128-30.

42. Lieberman DA, Keller FS, Katon RM, Rosch J. Arterial embolization for massive upper gastrointestinal tract bleeding in poor surgical candidates. Gastroenterology. 1984;86(5Pt1):876-85.

43. Park CH, Min SW, Sohn YH, Lee WS, Joo YE, Kim HS et al. A Prospective, Randomized Trial of Endoscopic Band Ligation vs. Epinephrine Injection for Actively Bleeding Mallory-Weiss Syndrome. Gastrointest Endosc. 2004;60:22-7.

44. Huang SP, Wang HP, Lee YC, Lin CC, Yang CS, $\mathrm{Wu}$ MS et al. Endoscopic Hemoclip Placement and Epinephrine Injection for Mallory-Weiss Syndrome with Active Bleeding. Gastrointest Endosc. 2002;55(7):842-6.

45. Yamaguchi Y, Yamato T, Katsumi N, Morozumi K, Abe T, Ishida $\mathrm{H}$ et al. Endoscopic hemoclipping for upper GI bleeding due to Mallory-Weiss syndrome. Gastrointest Endosc. 2001;53(4):427-30.

46. Fujisawa N, Inamori M, Sekino Y, Akimoto K, Iida $\mathrm{H}$, Takahata A et al. Risk factors for mortality in patients with Mallory-Weiss syndrome. Hepatogastroenterol. 2011;58(106):417-20.

Cite this article as: Albalawi $\mathrm{A}$, Alabbadi $\mathrm{H}$ Almoqbell T, Alsayari O, Aljohani A, Almana O, et al. The prevalence and risk factors for Mallory-Weiss syndrome: a systematic review and meta-analysis. Int J Community Med Public Health 2021;8:3096-106. 